Bildern befaßt, sagte zunächst, Frl. Rittmeyer hätte vollkommen recht, denn das Bild sei eine Kopie des 17. Jahrhunderts. Vom Kopf und von der Inschrift wurden Röntgenaufnahmen gemacht. Auch beim Durchleuchten wurden keine Unterschiede gefunden, d. h. es handelt sich also nicht um ein übermaltes Originalbild. Es steht übrigens "Parracelsus» in der Inschrift, also auch hier ein Fehler wie im Vornamen und in der Datierung. Frl. Dr. Rittmeyer beantragte, daß Frau Dr. Margarete Pfister-Burkhalter, erste Assistentin am Kupferstichkabinett des Kunstmuseums Basel, die bereits einen Zettelkatalog über die Paracelsus-Bildnisse angelegt, also in dieser Materie vorgearbeitet hatte, die Untersuchungen weiterführte, mit ihrem Material darstellte und verarbeitete. Sie kannte das St. Galler Bild nicht im Original, fand, es gehöre in die Reihe der Bilder in Schleißheim und Salzburg, die auf ein italienisches Original zurückgehen. $\mathrm{Zu}$ diesem Schluß war auch Frl. Dr. Rittmeyer gekommen, namentlich wegen des «f» statt «ph» im Namen Theophrastus.

Es steht somit fest, daß das St. Galler Bildnis aus dem 17. Jahrhundert stammt und nicht das Schobinger Original ist, sondern eine wahrscheinlich während den Schobingerschen Erbstreitigkeiten 1652-1657 untergeschobene Kopie desselben. Vergleichende Porträtstudien aus dieser Zeit führten mich auf den Zuger Maler Brandenberg. Frl. Dr. Rittmeyer bemerkt dazu: "Ihre Vermutung, daß um die Zeit der Erbstreitigkeiten das Original aus St. Gallen verschwand, erscheint mir sehr einleuchtend. Als Kopist mußte ein Ortsfremder berufen werden, was sich auch wieder reimt. Auch die Eintragung eines Schobinger um 1657, der um den Sachverhalt wußte (,ex archetypo depictus $\left.{ }^{6}\right)$ fand ich anderswo tatsächlich für Kop i e.»

\title{
William Harvey—a Speculative Note
}

\author{
By K. J. Franklin
}

(St. Bartholomew's Hospital Medical College, London)

John Aubrey (1813, 2, 380), in his account of Harvey, included the following passage. "After Oxford was surrendered, which was 24 July, 1646, he came to London, and lived with his brother Eliab, a rich merchant in London, on... hill, opposite to St. Lawrence, Poultry, where 
was then a high leaden steeple (there were but two, viz, this and St. Dunstan's in the East), and at his brother's country house at Roe-hampton. His brother Eliab bought, about 1654, Cockaine-house, now (1680) the Excise-Office, a noble house, where the Doctor was wont to contemplate on the leads of the house, and had his severall stations, in regard of the Sun, or wind. He did delight to be in the darke, and told me he could then best contemplate. He had a house heretofore at Combe, in Surrey, a good air and prospect, where he had caves made in the earth, in which in summer time he delighted to meditate."

Through the researches of Mr. Clarence G. Paget (Paget, 1929, 37, 57; 1937, 71), Coombe Lodge was in comparatively recent times identified as the house in which Harvey lived at Croydon. Dr. Mervyn Gordon and Lord Horder visited it in company with Mr. Paget in 1947, and, helped by the gardener, they attempted to locate the caves mentioned by Aubrey. Though their quest was unsuccessful, Dr. Gordon thought the caves might still be there, perhaps in the chalk of the rising ground.

It was at Combe, towards the end of 1650, that Dr. George Ent, President of the College of Physicians, made his historic visit to Harvey and secured for publication, from the latter, the manuscript of Exercitationes de generatione animalium.

From all the above, it seems highly probable that Harvey's second great published work was thought out in the dim light of the caves which he had had made in the grounds of Coombe Lodge. And that probability makes one wonder if his first great work was similarly conceived while comparative darkness aided the contemplative spirit.

What are the known facts? The first which one may mention is that in 1594 the first permanent anatomical theatre was built, in an upper room of the University of Padua building, for Hieronymus Fabricius of Aquapendente 1533?-1619). It occupied the greater part of the room. "There were six concentric galleries so narrow that spectators had perforce to stand, so little above one another that the heads in one were only three feet above those in the one below. A tall man could not have stood upright without obscuring the view of the man behind and above him, and the head of the most distant spectator was only twenty-five feet away from the object of demonstration. The theatre held about three hundred people, and a calculation shows that there was just space for this number. In the small oval at the bottom was a table for the body, or the part of it, which was to be dissected, and the space around 
this was reserved for the Professors of Anatomy, the Rectors of the City, the Rectors of the School, the Councillors and members of the medical College, and representatives of the Venetian nobility. Reference to the plans will show that these dignitaries could not have been present in any large number at a given time. The first gallery was occupied by the Councillors of the 'Nations' (many mediaeval Universities were divided up into 'Nations'), and the ones above by students. The theatre was lighted by two candalebra, each having three candles, and by eight lamps held by that number of students. Apart from this illumination the [windowless] theatre was in darkness" (Franklin, 1933, 28) ${ }^{1}$.

Five more facts have to be added to the above. They are:

1) That Fabricius first saw valves in veins during a dissection which he made in 1574 .

2) That about five years later he began to demonstrate them.

3) That in 1603 he produced his monograph-De venarum ostiolisupon them, but missed their function through adherence to Galenic views.

4) That Harvey studied under Fabricius at Padua from 1600 to 1602.

5) That it was a consideration of the venous valves which first induced him to think of a circulation of the blood.

Robert Boyle provides the evidence for this last statement, for in 1688 he wrote: "... when I asked our famous Harvey, in the only Discourse I had with him (which was but a while before he dyed), what were the things that induc'd him to think of a Circulation of the Blood? He answer'd me, that when he took notice that the Valves in the Veins of so many several Parts of the Body, were so Plac'd that they gave free passage to the Blood towards the Heart, but oppos'd the passage of the Venal Blood the Contrary way: He was invited to imagine, that so Provident a Cause as Nature had not so Plac'd so many Valves without Design; and no Design seem'd more probable, than That, since the Blood could not well, because of the interposing Valves, be Sent by the Veins to the Limbs; it should be Sent through the Arteries, and Return through the Veins, whose Valves did not oppose its course that way." On the basis of the facts which have been mentioned, it appears very

1 Italics not in original. 
likely that Harvey, as he watched the venous valves being demonstrated in the dim light of the lecture theatre at Padua, became aware of the wrongness of the functions which Fabricius was ascribing to the structures in question; further, that the contemplative mood induced by the relative darkness of the theatre provided the right medium for the development of the true answers to the problems, and that the hypothesis of the blood circulation was suddenly conceived in Harvey's mind.

One can even go farther in these speculations, and suppose that Harvey, having realized-consciously or unconsciously-what he owed in this first major instance to the relative darkness, sought similarly dim surroundings when, nearly half a century later, he was engaged upon his second 'great work and wished for absence from external distractions while he thought about it.

These are, admittedly, nothing but surmises built up upon a sentence or two from the not always reliable John Aubrey. There are, however, many modern examples of major ideas occurring to scientists under conditions similar to those which have been suggested in Harvey's case, and at least one Nobel laureate in physiology has publicly acknowledged that the idea for his fundamental research came to him in a dream, to remain with him on his awaking. So it is, perhaps, not out of place for the scientist sometimes to relax and to let his thoughts wander as they will; indeed, this may be the right counterpart to the severely self-disciplined life which he must lead, for the greater part of his time, in the laboratory.

\section{Addendum}

Mr. W. J. Bishop, Librarian of the Wellcome Historical Medical Museum, who very kindly read this note in its draft form, recalled that Thomas Howard, second Earl of Arundel, had many caves or «grotts about his house, cutt in the sandy sides of hills, wherein he delighted to sit and discourse" (Aubrey, 1813, 2, part 2, 474). A fine engraving of the house in question, at Albury in Surrey, is reproduced in Mary S. F. Hervey's book and it shows clearly, according to Mr. Bishop, the sand hills at the side. As Thomas Howard was intimate, from 1635 onwards, with "that little perpetual movement called Dr. Harvey" (see D'Arcy Power, 1917; 1931), it is very possible that the digging of the caves at Albury suggested the similar excavations at Coombe Lodge. 


\section{References}

1) Anon. (1938). Lancet, I, 94.

2) Aubrey, J. (1813). "Letters written by Eminent Persons in the Seventeenth and Eighteenth Centuries: to which are added, Hearne's Journeys to Reading, and to Whaddon Hall, the seat of Browne Willis, Esq. and Lives of Eminent Men." London: Printed for Longman, Hurst, Rees, Orme, and Brown, Paternoster-Rowa; and Munday and Slatter, Oxford.

3) Boyle, R. (1688). "A Disquisition about the Final Causes of Natural Things", 157-158.-London: Printed by H.C. for John Taylor, at the Ship in St. Paul's Church-Yard.

4) Franklin, K. J. (1933). Facsimile edition, with introduction and translation, of "De venarum ostiolis", 1603, of Hieronymus Fabricius of Aquapendente.-Springfield, III., and Baltimore Md.: Charles C Thomas.

5) Gordon, M. H. (1947). Unpublished notes on a visit with Lord Horder to Coombe Lodge.

6) Hervey, Mary S. F. (1921). "The life, correspondence and collections of T. Howard, Earl of Arundel."-Cambridge: At the University Press.

7) Paget, C. G. (1929). "By-Ways in the History of Croydon."-Croydon: The Central Library, Town Hall.

8) Paget, C. G. (1937). "Croydon Homes of the Past."-Croydon: The Central Library, Town Hall.

9) Power, D'Arcy, (1917). "A revised chapter in the life of Dr. William Harvey, 1636." Proc. R. Soc. Med., 10, 33-59. Reprinted in:

10) Power, D'Arcy, (1931). "Selected writings 1877-1930."-Oxford: At the Clarendon Press.

11) Spencer, H. R. (1921). Harveian Oration.

\section{Uber Lichtenbergs Anteil an der Ophthalmologie seiner Zeit}

\section{Von F.P. Fischer, Utrecht}

Der Zufall spielte mir einen Brief von Georg Christoph Lichtenberg an Goethe zu, der zwar in Lichtenbergs Briefen, herausgegeben von Leitzmann und Schüddekopf, Leipzig 1901, aufgenommen ist und auch schon vorher im Goethe-Jahrbuch, 18. Band, 1897, abgedruckt wurde, den Augenärzten aber ebenso unbekannt zu sein scheint, wie er mir war. Ich will diesen Brief, der der wichtigste ist aus dem Briefwechsel Lichtenbergs mit Goethe über das Farbensehen, darum hier wiedergeben. Wie sicherlich jeden, der diesen Brief liest, veranlaßte er auch mich, in Lichtenbergs Schriften nach weiteren Spuren seiner Beschäftigung mit den 